\title{
Yönetim ve organizasyon araştırmalarında yorumlayıcı fenomenolojik analiz yönteminin kullanılması: Sistematik bir inceleme
}

The use of interpretative phenomenological analysis (IPA) in management and organization studies: A systematic review

\author{
Halit Keskin ${ }^{1}$ \\ Zeynep Aksoy² \\ Selahaddin Şamil Fidan ${ }^{3}$
}

1 Prof. Dr., Yıldız Teknik Üniversitesi, İ.I.B.F., İşletme Bölümü, Yönetim ve Organizasyon A.B.D., İstanbul, Türkiye hkeskin@yildiz.edu.tr

ORCID: 0000-0003-4432-3998

${ }^{2}$ Arş. Gör., Yıldız Teknik Üniversitesi, İ.İ.B.F., İşletme Bölümü, Örgütsel Davranış A.B.D., İstanbul, Türkiye zaksoy@yildiz.edu.tr

ORCID: 0000-0003-1585-4992

${ }^{3}$ Arş. Gör., Yıldız Teknik Üniversitesi, İ.İ.B.F., İşletme Bölümü, Örgütsel Davranış A.B.D., İstanbul, Türkiye ssfidan@yildiz.edu.tr

ORCID: 0000-0002-7643-2139

\section{Sorumlu Yazar/Corresponding Author:}

Halit Keskin,

Yıldız Teknik Üniversitesi, İ.İ.B.F., İşletme Bölümü, Yönetim ve Organizasyon A.B.D., İstanbul, Türkiye, hkeskin@yildiz.edu.tr

\section{Başvuru/Submitted: 1/09/2021}

Revizyon/Revised: 20/10/2021

Kabul/Accepted: 28/10/2021

Yayın/Online Published: 25/12/2021

Attf/Citation: Keskin, H., \& Aksoy, Z., \& Fidan, S.Ş., Yönetim ve organizasyon araştırmalarında yorumlayıcı fenomenolojik analiz yönteminin kullanılması: Sistematik bir inceleme, bmij (2021) 9 (4): 1437-1451., doi: https://doi.org/10.15295/bmij.v9i4.1925
Öz

$\mathrm{Bu}$ çalışmada, yorumlayıcı fenomenolojik analiz (YFA) yöntemini bir nitel araştırma deseni olarak kullanan yönetim ve organizasyon çalışmalarının sistematik bir şekilde incelenmesi ve YFA yönteminin Türkçe alan yazınına tanıtılması amaçlanmıștır. Bu kapsamda, Web of Science veri tabanında bulunan 17 YFA araştırması YFA'nın doğası ve temel özellikleri baz alınarak, amaç, araştırma sorusu, örneklem, sektör ile unvan bilgisi ve veri yöntemi açısından sistematik bir şekilde değerlendirilmiştir. Çalışmanın sonucunda, örneklemde bulunan 17 çalışmanın tamamında işyerinde deneyimlenen çeşitli fenomenlerin ele alındığı tespit edilmiştir. Sadece 9 çalışmada amaçlı örnekleme tekniği kullanıldığı bulunmuştur. Ayrıca örneklemde bulunan çalışmaların yalnızca 6 tanesinde homojen örneklem vurgusu yapılırken, çalışmaların çoğunda homojen örneklemden bahsedilmediği görülmüş̧ür. YFA araştırmalarından bazılarının tek bir ülkeden veri topladığı, bazılarının ise birden fazla ülkeden veri topladığı bulunmuştur. Örneklemde bulunan çalışmalardan yalnızca ikisi Türkiye'de veri toplamıştır. Bunun yanı sıra, 15 örgütsel YFA çalışmasında yalnızca yarıyapılandırılmış görüşme yönteminin kullanıldığı tespit edilmiştir. Çalışmanın bulguları sonucunda, gelecekte yapılacak yorumlayıcı fenomenolojik analiz çalışmalarına yol gösterici nitelik taşıan önerilerde bulunulmuştur.

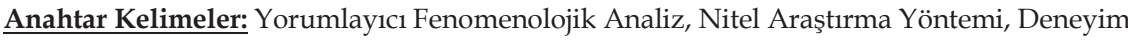
Jel Kodlari: L20, M10

\begin{abstract}
This study systematically reviews management and organization studies that used interpretative phenomenological analysis (IPA) as a qualitative research design and introduced IPA to Turkey's management and organization studies literature. Within this scope, 17 IPA studies included in the Web of Science database were systematically examined in terms of the aim of the research, research question, sampling, industry, the profession of participants, and data analysis method that reflect the nature of IPA. Results reveal that all 17 studies examined phenomena experienced in the organizational context. However, only nine studies used the purposive sampling method. Also, only 6 out of 17 studies used a homogenous sample, whereas other studies did not mention the homogenous sample term. Furthermore, while some studies collected data from a single country, other studies collected data from multiple countries. However, only two studies collected data from Turkey. In addition, 15 organizational IPA studies used semi-structured interviews as the data collection technique. Finally, this study makes guiding light suggestions to future IPA studies based on the research findings.
\end{abstract}

Keywords: Interpretative Phenomenological Analysis, Qualitative Research Methods, Experience Jel Codes: L20, M10 


\section{Extended Abstract}

The use of interpretative phenomenological analysis (IPA) in management and organization studies: A systematic review

\section{Literature}

Interpretative phenomenological analysis (IPA) is a new phenomenology-based qualitative research method that straightforwardly examines individuals' subjective experiences (Smith, Flowers, \& Larkin, 2009). In other words, IPA aims to uncover and understand personal meanings attached to the specific incidents. Therefore, the interpretation of phenomena made by subjects constitutes its core. In addition, it has adopted a double hermeneutic approach which implies sense-making what an individual makes sense of (Gill, 2014). It means that interpretation of phenomena occurs through the joint effort of participants and researchers (Smith et al., 2009, p. 81). Due to the closeness of its nature to psychological principles of perception and sensemaking, IPA has been featured prominently in psychology research (Smith, 2011). In recent years, the increased need for phenomenon-based theories that represent organizational realities based on practical social life much better, minimize the knowledge and understanding filters between theory and practice and effectively respond to organizational problems makes phenomenon-based research has received significant attention in management and organization studies (Schwarz \& Stensaker, 2014; 2016). However, a considerable amount of management and organizational scholars that used IPA in their studies lack understanding of the nature and characteristics of IPA, leading them to apply IPA's research principles and practices inappropriately. When considering the importance of the IPA method for organization studies, this problem creates a need to introduce IPA to the management and organization literature by critically reviewing and pointing out studies that used IPA correctly. The current study thus aims to critically review management and organization studies that used IPA as a research design. This study contributes to the management and organization studies discipline by providing a valuable handbook to scholars in Turkey to guide their future IPA studies. In this regard, the current research also plays a pioneering role in responding to the research call made by Smith (2004). IPA studies should be progressively conducted in non-English speaking countries. As the first review article that examines IPA studies in the management and organization discipline, this study contributes to relevant literature by enhancing the understanding of IPA's nature and exemplifying how to conduct good IPA research.

\section{Design and method}

This study systematically examined 17 IPA studies that were also systematically reached from the Web of Science database. These studies were reviewed to uncover whether they adopted and used IPA correctly by considering some criteria, including the aim of the research, the type of research question, sampling technique, the use of homogenous sample and data collection method.

\section{Findings and discussion}

Results revealed that all 17 studies examined phenomena experienced in the organizational context. Only nine studies used the purposive sampling method. Also, only 6 out of 17 studies used a homogenous sample, whereas other studies did not mention the homogenous sample term. While some studies collected data from a single country, others collected data from multiple countries. Only two studies collected data from Turkey. In addition, 15 organizational IPA studies used semi-structured interviews as the data collection technique. All studies in the sample used IPA as a research design rather than a data analysis method. Also, research questions of all studies were generated to explore an "experience" inductively, not exploring the preidentified cause-effect relationships in a hypothetico-deductive way (Smith et al., 2009). Therefore, these studies can be shown as good IPA studies, and future research should take these studies as an example. However, based on the findings of this study that represent open for development points, we make some vital recommendations for future research. First, future studies should generate samples homogeneously to adhere to IPA principles and give this information in the manuscript to help readers interpret research findings and support the transferability of results. Second, in response to the research call by Smith (2011), organizational scholars should conduct IPA studies in Turkey, which provides a fruitful research context. It contributes to understanding organizational phenomena in the Turkish context and developing theories unique to this context. Lastly, future research should use new data collection techniques like painting, drawing and role-playing in addition to semi-structured interviews to obtain richer and deeper participant responses. 


\section{Giriş}

Yorumlayıcı fenomenolojik analiz (YFA), kişisel anlamın ve deneyimin detaylı bir şekilde keşfedilmesine odaklanan yeni bir yaklaşım türüdür (Gill, 2014). YFA'nın fenomenolojik kökeni, katılımcıların bireysel deneyimlerinin zenginliğine odaklanması gerektiğini vurgular. YFA'nın yorumlayıcı kökeni ise, araştırmacıları, katılımcıların bireysel deneyimine nasıl anlam yüklediklerini tespit etmeye yönlendirir (Millward, 2006) ve katılımcıların anlam verme etkinliklerine ilişkin empatik, eleştirel ve kavramsal yorum yapmaları için araştırmacıları teşvik eder (Landells ve Albrecht, 2017). Bu bağlamda, YFA'nın temel amacı, kişisel yaşanmış deneyimin anlamına odaklanmak ve kişinin belli bir olay ya da süreçle (fenomen) ilişkisini keşfetmektir. Bir araştırma projesi için YFA'yı kullanmak, katılımcıların deneyimlerine yükledikleri anlamları keşfetmeyi, betimlemeyi, yorumlamayı ve önceliklendirmeyi ifade eder. Bu yüzden, YFA araştırmacılarının, katılımcıların zengin ve detaylı kişisel açıklamalarına erişmesi gerekmektedir (Smith, Flowers ve Larkin, 2009).

YFA sağllk psikolojisi alanı başta olmak üzere klinik, danışmanlık, sosyal ve eğitim psikolojisi alanlarında yaygın bir şekilde kullanılmaktayken (Smith vd., 2009), yönetim alanında da kullanılmaya başlanmıştır (Jayawardena-Willis, Pio ve McGhee, 2019). Örneğin, önceki çalışmalar örgütsel ortamda kadın çalışanların gebelik ve gebelik sonrası dönemde anneliğe geçiş deneyimlerini (Millward, 2006), çalışanların örgütsel politikalara ilişkin deneyimlerini (Landells ve Albrecht, 2017), kurumsal sürdürülebilirlik bağlamında çalışanların korku deneyimlerini (Gill ve Burrow, 2018), girişimcilerin girişimci-iş veren olma deneyimlerini (Williams, Pritchard, Miller ve Reed, 2020), orta düzey yöneticilerin büyük veri ve iş analitiği deneyimlerini (Sengupta, Mittal ve Sanchita, 2020), COVID-19 pandemisi sürecinde kadın akademisyenlerin aile ve iş deneyimlerini (Parlak, Celebi Cakiroglu ve Oksuz, 2021) nasıl anlamlandırdığını keşfetmek amacıyla YFA kullanılmıştır. Bu çalışmaların odağında katılımcların tecrübe ettikleri önemli bir deneyim ve bu deneyime ilişkin katılımclların yükledikleri anlamlar yer almaktadır.

YFA'nın epistemolojik doğasında idiyografi, tümevarımsal ve sorgulayıcı olarak üç temel metodolojik prensibin sentezi yer almaktadır (Tomkins ve Eatough, 2014). İdiyografi prensibi, YFA araştırmacılarını, katılımcıları kendi bağlamları içerisine yerleştirerek onların kişisel bakış açılarını keşfetmeye ve genel iddialarda bulunmadan önce her bir vakanın ayrıntılı incelenmesine yönlendirir. Bu anlamda, idiyografi prensibi gerçekliğe ilişkin içeriden bakış açısına öncelik verir (Smith vd., 2009). Tümevarımsal prensip, bireyin perspektifinden gelen anlamların temel alınarak kuramın geliştirilmesine yönlendirir. Aksi takdirde, bireyin yaşanmış deneyiminin önceden var olan kategorilere indirgenerek deneyimin içerisindeki zenginliğin ve yorumlama sürecinin kısıtlanması söz konusu olacaktır (Millward, 2006). Sorgulayıcı prensip ise, bireyin deneyimlendirme sürecine empatik ve eleştirel bir şekilde yaklaşmaya yönlendirir (Tomkins ve Eatough, 2014).

YFA'nın üç temel prensibi, YFA uygulayıcıları için önemli olmasına rağmen, örgütsel ortamda YFA'yı kullanan çalışmalarda bu prensiplerin yeterince dikkate alınmadığı gözlenmiştir. Yönetim araştırmalarında YFA'yı kullanan bazı çalışmalar (örneğin, Ahn, Dik ve Hornback, 2017; Dias ve Teixeira, 2017), araştırmacıların önceden belirlediği varsayımlarıyla odak fenomenin zenginliğini tümdengelimsel varsayımlarla belli kategorilere indirgemektedir. YFA'nın örneklem sayısı konusunda esnek bir yaklaşımının olmasından dolayı (Smith vd., 2009), YFA bazı örgütsel çalışmalarda sadece örneklem sayısını meşrulaştırma aracı olarak kullanılıyor olabilir. Bu tarz sorunlar YFA'yı örgütsel bağlamda doğrudan tanıtan bir çalışmanın eksikliğinden kaynaklanabilir. Çalışma kapsamında YFA'yı örgütsel bağlamda tanıtan ulusal ve uluslararası alan yazınında herhangi bir çalışmaya rastlanılmamıştır. Örgütsel bağlamdaki YFA'yı uygulayan çalışmalara yönelik herhangi bir sistematik inceleme çalışmasına da rastlanılmamıştır. Ayrıca, YFA'nın örgütsel bağlamda baskın olan makro perspektifleri mikro perspektiflerle dengeleme potansiyeli (Williams vd., 2020) ve yönetim alanında fenomen odaklı çalışmaların gerçekleştirilmesi çă̆rısına katkı sağlama işlevi ${ }^{1}$ (Schwarz ve Stensaker, 2014; Schwarz ve Stensaker, 2016; Ployhart ve Bartunek, 2019) vardır. Ana dili İngilizce olmayan toplumlarda YFA uygulamalarının yaygınlaştırılması çağrısı ${ }^{2}$ (Smith, 2004) da dikkate alındığında,

\footnotetext{
${ }^{1}$ Fenomen odaklı araştırmalar, iyi anlaşılmamış yönetsel fenomenlere yönelik derinlemesine içgörü ve anlayış sağlar (Van de Ven, 2016). Çalışanların, araştırmacıların teoride beklediğinden farklı eylemde bulunma, mevcut teorinin bilgeliğinin örgütsel bağlamdaki saha gerçekliklerini açıklayamama, sahada tamamen yeni ya da benzeri görülmemiş bir örgütsel olayla karşılaşma durumları dikkate alındığında, fenomen odaklı araştırmaların önemi ortaya çıkar. Bu anlamda, fenomen odaklı araştırmaların amacı, sahanın içerisinde ortaya çıkan yönetsel ya da örgütsel fenomeni anlamaktır. Böylece, sahada yaşanan gerçeklikler bilim dünyasında tartışılma zeminine kavuşur (Schwarz ve Stensaker, 2014; 2016). Fenomen odaklı çalışmalar gerçek dünyanın sorunlarını gündeme alarak araştırma sorularını şekillendirdiği için bu tarz çalışmaların sahadaki meydan okuyucu sorunların çözümlenmesine katkı sağlama işlevi vardır (Mathieu, 2016).

2 Türkiye'de örgütsel deneyimleri ele alan YFA çalışmalarının yapılması, bu bağlama özgü teorilerin ve çözüm önerilerinin geliştirilmesine katkı sağlayacaktır.
} 
YFA'nın örgütsel bağlamda tanıtılması önem taşımaktadır. Söz konusu ihtiyaçlar göz önüne alındığında, bu çalışma kapsamında YFA'nın metodolojik olarak tanıtılması ve örgütsel ortamda YFA'yı uygulayan çalışmaların sistematik bir şekilde incelenmesi amaçlanmaktadır. Böylece, bu çalışma hem YFA'nın metodolojik doğasının açıklanmasına hem de örnek çalışmalarla YFA'nın bir araştırma tasarımı olarak nasıl kullanıldı̆̆ının gösterilmesine katkı sağlayacaktır.

Çalışmanın ilk aşamasında YFA'nın doğası ele alınmıştır. İkinci aşamada, YFA'nın temel özellikleri kapsamında YFA'da araştırma sorularının oluşturulması, YFA'da örneklem ve veri analizi süreçleri aydınlatılmaya çalışılmıştır. Üçüncü aşamada, YFA'yı kullanan örgütsel çalışmalar sistematik bir şekilde belirlenmiştir. YFA'yı örgütsel bağlamda kullanan çalışmalar amaç, araştırma sorusu, örneklem bilgisi, sektör ve unvan, veri toplama yöntemi açısından incelenmiştir. Sistematik inceleme sonrasında, YFA'yı kullanan örgütsel çalışmaların YFA'nın doğasını ne kadar yansıttığı ele alınmıştır ve gelecek araştırmacıların nelere dikkat etmesi gerektiği konusunda yönlendirmelerde bulunulmuştur.

\section{YFA'nın doğası: Fenomenoloji, hermeneutik ve idiyografik}

YFA nitel, deneyimsel ve psikolojik araştırma yaklaşımıdır. YFA'nın doğası üç temel alanın yönlendirmesiyle şekillenir: fenomenoloji, hermeneutik ve idiyografik (Smith vd., 2009). YFA'nın doğası fenomenolojiye dayanır. Bu yüzden, YFA araştırmacıları fenomenolojik metotların beş genel özelliğini dikkate alır: 1) fenomenoloji felsefesinin ortak temeli, 2) bireysel deneyimlerin anlamın keşfetmeye yönelik üst düzey bir ilgi, 3) deneyim sahibi bireyin bakış açısından fenomeni kavramaya çalışma, 4) homojen örneklem seçimi ve 5) tematik analizlerin kullanımı (Gill, 2014). YFA araştırmacıları fenomenolojiyle tutarlı olarak, canlı ve iz bırakmış deneyimleri odağa alır. İnsanlar hayatlarında önemli yeri olan deneyimlerle meşgul olduklarında, bu deneyimlerin hayatlarında ne ifade ettiği ve öneminin ne olduğu üzerinde derinden düşünürler. YFA araştırmacıları, insanların bu yansıtmalarına ulaşmaya çalışır. Örneğin, işe yeni başlama, ilk çocuk sahibi olma, yakın ebeveynini kaybetme, yabancı bir ülkeye göç etme deneyimleri gibi insanların hayatlarındaki önemli kırılma noktaları YFA araştırmalarına konu olabilir (Smith, 2009). YFA bir objenin ya da olayın objektif açıklamasını yapmak yerine bir obje ya da olayın bireysel algılamasına, yorumlamasına ya da açıklamasına odaklanır. Önceden gerekçesi yapılmış bilimsel hipotezler ya da soyut kavramsallaştırmalar yerine katılımcıların yaşanmış deneyimlerini detaylı bir şekilde incelemeyi ve anlamlandırmayı amaçlar (Smith ve Osborn, 2015).

YFA'nın teorik arka planı hermeneutik yaklaşımından beslenir. Hermeneutik, anlama ve yorumlama teorisi olarak tanımlanır. Heidegger, hermeneutik yaklaşımı, "fenomenolojiyi yorumlama girişimi" olarak tanımlamaktadır. Bu anlamda, YFA yorumlayıcı fenomenolojik yaklaşımı temsil eder. YFA araştırmacıları Heidegger'i takip ederek, bir fenomenin nasıl ortaya çıktığını inceleyerek ilgili fenomenin görünümünü kolaylaştırır ve anlamlandırır (Smith vd., 2009). Diğer bir deyişle, Heidegger ve YFA için fenomenoloji, anlamları keşfetmek veya ortaya çıkarmakla ilgilidir (Smith, 2019).

YFA'nın çeşitli fenomenolojik metodolojilerden farkı, "çift hermeneutik" sürecini benimsemiş olmasıdır (Gill, 2014). Çift hermeneutik, iki aşamalı yorumlama sürecini ifade eder. Birinci aşamada, katılımcılar kendi dünyalarını anlamlandırmaya çalışır. İkinci aşamada ise, araştırmacılar katılımcıların anlamlandırmaya çalıştığı dünyayı anlamlandırma girişimde bulunur (Smith ve Osborn, 2015). Bu bakımdan, YFA araştırmacısının çift rolü vardır. Birinci rolde, araştırmacı bir anlamda katılımcı gibidir ve dünyayı anlamlandırmak için benzer zihinsel ve kişisel beceri ve kapasitelerini kullanır. Diğer taraftan, ikinci rolde, araştırmacı katılımcıya benzemez. Bu rolde, araştırmacı katılımcının deneyimine yalnızca katılımcının deneyim hakkında aktardığı kadarıyla erişebilir. Bu bağlamda, katılımcının deneyime ilişkin anlamlandırması birinci dereceden anlamlandırmayken, araştırmacının anlamlandırması ikinci dereceden anlamlandırmadır (Smith vd., 2009).

YFA araştırmalarında "çift hermeneutik", "empatik hermeneutik" ile "eleştirel hermeneutik" yaklaşımlarının sentezlenmesini de ifade eder. Empatik hermeneutik, içsel bir perspektifle orijinal deneyimi katılımcının kendi terimleriyle yeniden inşa etmeye çalışırken; eleştirel hermeneutik, fenomene ışık tutmak için dışarıdan farklı teorik perspektifleri (örneğin, psikanaliz) kullanır (Smith vd., 2009). YFA bir fenomenin neye benzediğini katılımonın bakış açısıyla anlamlandırmaya çalışırken (içsel perspektifle katılımcının yanında yer alarak), aynı zamanda katılımcının metinlerine yönelik eleştirel ya da sorgulayıcı soruları gündeme getirir: (i) Katılımcı burada neye ulaşmak istiyor? (ii) Burada amaçlı olmayan bir aktarım mı var? (iii) Burada katılımcının daha az farkında olabileceği bir durum seziyor muyum? (Smith ve Osborn, 2015). Eleştirel hermeneutik yaklaşımının, katılımcının söylediklerine yönelik kritik soruları gündeme getirmesi, katılımcının deneyimlerine farklı bir pencereden bakılmasını sağlar. Bu anlamda, başarılı YFA araştırmaları her iki yaklaşımı sentezleyebilir. Böylece, yorumlama süreçleri üst düzeyde gerçekleşir (Smith vd., 2009). 
YFA'nın idiyografik yapısı, YFA'yı diğer fenomenolojik metodolojilerden ayırır (Gill, 2014). YFA araştırmalarında, bir vaka kendi bağlamında tamamen anlamlandırılarak, vakanın detaylı incelenmesi yapılır. Vaka kapsamında, bir kişinin deneyiminin neye benzediği ve bu deneyimin ne anlam ifade ettiği detaylı bir şekilde irdelenmeden, ikinci vakaya geçiş yapılmaz. Birinci vakanın incelenmesi tamamlandıktan sonra da ikinci vaka kendi dinamikleri içerisinde detaylı bir şekilde incelenir ve anlamlandırılır. Sonrasında, vakalar arasındaki benzerliklerin ve farklılıkların değerlendirilmesi yapılır. YFA çalışmaları bu anlamda güçlü bir şekilde idiyografik yapıya sahiptir (Smith, 2004). YFA idiyografik odağından dolayı, küçük, amaçlı bir şekilde seçilmiş ve dikkatlice yerleştirilmiş örneklemleri tercih eder. Hatta, tek vakadan oluşan fenomenolojik çalışmaları teşvik eder (Smith vd., 2009). Bu bağlamda, YFA çalışmalarında idiyografiyle uyumlu bir şekilde bireysel vaka çalışmalarının detaylı incelemesi yapılır, bireyler hakkında spesifik açıklamalarda bulunulur, bireysel vakaların benzerliklerinden ve farklılıklarından yola çıkılarak dikkatli bir şekilde daha genel iddialara ulaşılır (Smith ve Osborn, 2015).

\section{YFA'nın temel özellikleri}

YFA'nın temel özellikleri, (i) YFA'da araştırma sorularının oluşturulması, (ii) YFA'da örneklem özellikleri, (iii) YFA'da veri analizi ve (iv) YFA'da kalite ve geçerlilik olmak üzere dört temel başlıkta ifade edilebilir.

\section{YFA'da araştırma sorularının oluşturulması}

Araştırma soruları içerisinde bir sorgulamanın değerleri, dünya görüşü ve yönü yer alır. Araştırma soruları ne tür bilginin üretileceğini etkiler (Trede ve Higgs, 2009). Bu bağlamda, YFA'yı kullanmak isteyen araştırmacıların, araştırma sorusu tasarım sürecinde YFA'nın temel doğasını dikkate alması gereklidir.

YFA'yı kullanan araştırmacıların araştırma sorularında, katılımcıların karşılaştıkları özel durumları nasıl algıladığı ve katılımcıların kişisel ve sosyal dünyalarını nasıl anlamlandırdığı odağa alınır (Smith ve Osborn, 2015). YFA'nın araştırma soruları, insanların başlarına gelen ve bilişsel olarak tazeliğini koruyan önemli deneyimlere ilişkin algılarını incelemeyi temel alır. Katılımcıların hayatını ciddi anlamda etkileyen bu tarz deneyimler, onları ne olup bittiğine yönelik yansıtma yapmaya yönlendirir ve onların anlamlandırma mekanizmalarını harekete geçirir. YFA araştırma sorularında odağa alınan deneyimler oldukça güncel ve bireye özgü olabilir. Bir kişinin yaşamındaki büyük bir karar ya da dönüm noktası YFA araştırma sorusu örneği olarak verilebilir. Bu deneyimler devam eden nitelikte de olabilir. Devam eden bir durumu YFA için uygun kılan nitelik, deneyimlere ilişkin bilişsel süreçlerin tazeliğini ya da canlılığını korumasıdır. Burada dikkat edilmesi gereken, katılımcıların deneyimlerine yönelik anlam verme girişimlerinin olmasıdır (Smith, 2019).

YFA araştırmalarında anlamın ya da anlam vermenin ne ifade ettiği ve farklı düzeyleri Tablo 1'de yer almaktadir (Smith, 2019).

Tablo 1: Anlamin Tipolojisi

\begin{tabular}{|l|l|l|}
\hline Soru tipi & Analiz düzeyi & YFA'nın odak yoğunluğu \\
\hline 1. Bu ne anlama geliyor? & Sözlük & I \\
\hline 2. O, ne demek istiyor? & Pragmatik/metinsel & III \\
\hline 3. Bunun anlamı nedir? & Deneyimsel & IIIII \\
\hline 4. Bunun kimlik için anlamı nedir? & Var oluşsal & III \\
\hline 5. Hayat ne anlama gelir? & Var oluşsal & II \\
\hline
\end{tabular}

Kaynak: Smith, J.A. (2019). Participants and researchers searching for meaning: Conceptual developments for interpretative phenomenological analysis. Qualitative Research in Psychology, 16(2), 166-181.

Anlamın birinci düzeyi olan sözlük anlamında, "bu ne anlama geliyor" sorusu yer alır. Sorunun cevabı olarak, anlamın tam ya da gerçek bir karşılığı beklenir. Değerlendirilen kelimenin dilsel ya da sözlük tanımının tam olarak ne ifade ettiği sorgulanır. Anlam araştırmasının ikinci düzeyinde, daha pragmatik bir soru gündeme alınır: "bir metin parçası ya da bir ifade ne anlama gelir" ya da "O, ne demek istiyor". Herhangi bir konuşmada söylenenlerin anlaşılmak istenmesine yönelik "konuşmada bunu söylediğinde ne demek istedi" sorusunun cevabı bu düzeyde aranır. Üçüncü düzey, daha deneyimsel olanı ifade eder. Bu düzey, kişinin hayatında meydana gelen önemli deneyimlerin, kişi için ne anlam ifade ettiğiyle ilgilidir. Bu düzeyde ön plana çıkan araştırma soruları şunlardır: "Ciddi bir hastalık için pozitif tanı aldığımın söylenmesi benim için ne anlam ifade eder? İşyerinde terfi teklifi almış olmak, çalışan için ne anlama gelir?". Bu bağlamda, üçüncü düzeyde katılımcıların başına gelen ya da maruz 
kaldıkları herhangi bir şeyin deneyimsel önemine odaklanılır. YFA'nın araştırma sorusunun tasarlanması sürecinde bu üçüncü düzeye ağırlık verilir. Çünkü bu düzey katılımcıların deneyime ilişkin nasıl bir anlam yüklediğine odaklanır. Dördüncü düzey, var oluşsal anlamı ifade eder. Bu düzeyde, bir durumun ya da olayın katılımının kimliği için ne anlama geldiğinin sorgulaması yapılır. Son düzey ise, var oluşsal anlamı bir üst düzeye çıkararak yaşamın bir anlamı olup olmadığının irdelemesini yapar (Smith, 2019).

Tablo 1'deki anlamın tipolojisi düzeylerinden üçüncü düzey YFA'nın temel odağıdır çünkü bu düzey bir deneyimi ve deneyime katılımcının nasıl bir anlam yüklediğini odağa alır. Bununla birlikte, bu düzeyler birbirinden bağımsız değildir. Üçüncü düzeyin tatmin edici bir şekilde katılımcının anlam dünyasına nüfuz edebilmesi için birinci ve ikinci düzeylerin de dikkate alınması gereklidir.

\section{YFA'da katılımcıların belirlenmesi}

YFA çalışmalarında katılımcı grubunun üç temel özelliği vardır: 1) amaçlı örnekleme yoluyla seçilmesi 2) büyüklüğünün görece küçük olması ve 3) katılımcı grubunun homojen bir şekilde oluşturulması. YFA çalışmalarında, bireylerin deneyimlerine atfettikleri anlamların detaylı bir şekilde incelenmesi esas alınmaktadır. Bu sebeple, araştırmaya konu olan deneyim hakkında derin ve zengin paylaşımlarda bulunacak kişilerden veri oluşturulması kritik bir önem taşımaktadır. YFA araştırmacıları araştırma sorusunun odağında olan belli bir olayı ya da durumu yakından deneyimleyen kişileri amaçlı örnekleme yoluyla seçer (Smith vd., 2009). Diğer bir deyişle, YFA'da katılımcı grubu, görüşme sorularına anlamlı ve detaylı bir şekilde cevap verecek kişilerden oluşturulmaya çalışılır.

YFA'da katılımcı grubunun diğer temel özelliği ise büyüklügünün görece küçük olmasıdır. YFA çalışmalarında örneklemde bulunan her bir katılımcıyla uzun ve detaylı bir görüşme gerçekleştirilir ve her bir katılımcının görüşmesi ayrı ayrı derinlemesine analiz edilir (Smith, 2011). Katılımcı sayısı arttıkça, verinin yönetilmesi ve görüşmelerden elde edilen verilerin etkili bir şekilde analiz edilmesi zorlaşır (Smith, 2004). Diğer bir deyişle, bulguların anlamlı bir şekilde yorumlanma ve fenomenin zengin bir şekilde anlaşılabilme ihtimali düşer. Bunun yanı sıra, YFA çalışmalarında elde edilen bulguların genellenebilir olması gibi bir kaygı güdülmez (Smith vd., 2009). Temel amaç belli bir fenomeni detaylı bir şekilde anlamak ve deneyimlere dair spesifik bakış açılarını yakalamaktır. Bu anlamda, YFA çalışmalarında katılımcı grubu, bir olguya yönelik özel bir bakış açısını temsil eder (Smith vd., 2009). Belli bir deneyimi "benzer" perspektiflerle anlamlandırması beklenen görece az sayıda kişiden veri oluşturmak yeterli olur. Bu açıdan YFA çalışmalarında verinin niceliğinden çok nitelikli olması, yani örneklem içinde anlamlı benzerlik ve farklılıkların etkili ve zengin bir şekilde ortaya çıkarılması önem arz etmektedir (Smith vd., 2009). Dolayısıyla YFA çalışmalarında pratik ve teorik sebeplerden ötürü görece küçük katılımcı grupları tercih edilir.

Katılımcı grubu büyüklüğü hakkında kesin bir sayı verilmemekle birlikte, katılımcı grubunda kaç kişinin bulunacağı araştırma sorusuna, her bir bireysel vakanın zenginliğine, araştırmacının görüşme becerilerine ve araştırma kısıtlarına bağlı olarak belirlenir (Smith vd., 2009). Bunun yanı sıra, Smith vd. (2009) YFA çalışmalarına yeni başlayan öğrenci ve araştırmacılara veri oluşturma ve veriyi analiz edip yorumlama becerilerinin gelişmesi için tek bir araştırmada az sayıda görüşme (3-6 katılımcı ile) gerçekleştirmelerini önermektedir. Daha deneyimli YFA araştırmacıları ise görece daha büyük bir veri setiyle (4-10 katılımcı ile) analizlerini gerçekleştirebilirler.

Bunlara ek olarak, yorumlayıcı gelenekte deneyimler belli bir bağlam içerisinde değerlendirildiği için katılımcı grubunun homojen olması, belli bir bakış açısını ortaya çıktığı bağlamda yorumlamak açısından kritik bir önem taşımaktadır (Larkin, Eatough ve Osborn, 2011). Homojen katılımcı grubu vurgusu YFA'nın idiyografik doğasına uygun olarak katılımcı grubu içindeki benzerlikler (convergence) ve fikir ayrılıklarını (divergence) etkili bir şekilde ortaya çıkarmak için yapılmaktadır. Larkin, Shaw ve Flowers (2019, s. 182) homojenliği "bir olguya yönelik olası ortak bakıs açısı" olarak tanımlamaktadır. Bir katılımcı grubunun homojenliğini çoğunlukla ortak bir deneyim ve bu deneyimin benzer bakış açılarıyla anlamlandırılmasını etkileyen demografik özellikler belirlemektedir. Diğer bir deyişle, katılımcı grubunun ne kadar homojen olacağı grup içinde istenen benzerlik düzeyine göre şekillenir. Bu sebeple YFA araştırmacıları, katılımcıların araştııılan deneyime dair benzer bakış açılarını paylaşmalarına neden olabilecek temel özellikleri belirleyerek katılımcı grubunu homojen bir şekilde seçme gayreti gösterirler (Smith vd., 2009). Örneğin, başka bir ülkeye çalışmak için göç etmiş işçilerin çalışma deneyimlerini araştıran bir çalışmada, oluşturulacak katılımcı grubunun homojenliği şu kriterlere göre belirlenebilir: göç eden iş̧̧inin a) ne kadar süre önce göç ettiği, b) daha önce farklı bir ülkeye çalışmak için göç edip etmediği, c) yalnız ya da ailesiyle birlikte yaşayıp yaşamadığı, d) ana vatanı ile göç ettiği ülke arasındaki kültürel farklılık düzeyi vs. 
Ayrıca, araştırılan deneyim ortaya çıktığı bağlamda nadir görülüyor ise, katılımcı grubunun homojenliğini diğer kriterler değerlendirilmeksizin sadece ilgili deneyim belirleyebilir (Smith vd., 2009). Bazı durumlarda ise bir fenomenin farklı bakış açılarıyla değerlendirilmesi o fenomenin bütüncül ve detaylı bir şekilde anlaşılmasını sağlar (Smith vd., 2009). Böyle durumlarda, bir çalışmaya kendi içlerinde homojen olan 2 ya da daha fazla katılımcı grubu dahil edilebilir (Larkin vd., 2019). Örneğin, lider-üye etkileşimiyle ilgili deneyimlerin araştırıldığı bir çalışmada, liderler ve üyelerden oluşan iki ayrı örneklem grubuyla örneklemler içinde homojenlik sağlanmaya çalışılır. Bunun yanı sıra, Smith vd. (2009) ilk kez YFA çalışması yapacak araştırmacılara katılımcıları demografik özelliklere göre homojen gruplara ayırarak bir karşılaştırma çalışması yapmalarını önermektedir. Örneğin, ilk kez YFA çalışması yapacak bir doktora öğrencisi 3 aydır yurtdışında çalışan kadın çalışanlar ile 3 aydır yurtdışında çalışan erkek çalışanların deneyimlerini bir karşılaştırma çalışması yaparak araştırabilir. Böyle bir çalışmada, katılımcı gruplarının homojenliğini yalnızca cinsiyet faktörü belirlemektedir.

\section{YFA'da veri analizi}

YFA'da veri analizi tümevarımsal bir şekilde yapılır. Diğer bir deyişle, veri analizi önceden geliştirilmiş bir hipoteze ya da teoriye göre şekillendirilmeksizin tamamen veriye bağlı ve esnek bir şekilde gerçekleştirilir (Smith, 2004). YFA'ya özgü özelliklerden biri de her bir vakanın (katılımcı) tek tek analiz edilmesi ve katılımcılara özgü temalardan paylaşılan (ortak) temaların ortaya çıkarılmasıdır (Smith, 2011). Bu temelde, bireye özel temalar ile ortak anlayışı yansıtan temaların karşılıklı değerlendirildiği bir analiz yaklaşımı benimsenir. Böylece, YFA'nın idiyografik doğası yansıtılmaktadır (Smith, 2004). Bunun yanı sıra, YFA veri analizinde üç temel bileşenin olduğu söylenebilir: (i) katılımcının deneyimleri, (ii) katılımcının deneyimlerine yüklediği anlamlar ve (iii) araştırmacının katılımcının paylaştığı anlamlara yüklediği anlamlar (Smith vd., 2009). İlk bileşen betimleyici düzeyde, ikinci ve üçüncü bileşenler ise yorumlayıcı düzeyde analiz edilir. Araştırma süreci betimleyici analiz ile yorumlayıcı analiz sonuçları arasında sürekli karşılaştırmalar yapılarak yinelemeli bir şekilde tamamlanır ve araştırma bulguları YFA'nın çift-hermeneutik doğasına uygun bir şekilde katılımcı ve araştırmacının ortaklaşa çabasıyla ortaya çıar (Smith vd., 2009).

\section{YFA'da kalite ve geçerlilik}

Smith vd. (2009), YFA çalışmalarında kalite ve geçerlilik konularının birbiriyle yakından ilişkili olduğunu savunarak bu iki sorunsalın çözümüne ilişkin değerlendirme kriterleri ve stratejiler sunmuşlardır. Bu doğrultuda, Yardley (2000) tarafından kaliteli nitel araştırmaları belirlemek için öne sürülen kriterleri YFA'ya uyumlayarak, yüksek kaliteli YFA araştırmalarının şu özelliklere sahip olması gerektiğini ifade etmişlerdir: Deneyimlerin gerçekleştiği özel bağlamla birlikte ele alınması (bağlama duyarlılık), görüşmeler sırasında katılımcıyla olan ilişkilerde hassas ve dikkatli olma, görüşmelerin deneyime odaklı bir şekilde derinlemesine gerçekleşmesi, araştırma sorusunun YFA araştırma tasarımıyla uyumlanması (katılımcı grubunun amaçlı örnekleme yoluyla seçilmesi, katılımcı grubunun homojen olması vb.), veri analizinin YFA'nın idiyografik ve hermeneutik temellerini yansitacak şekilde yapılması, araştırma basamaklarının şeffaf bir şekilde açıklanması, araştırma sonuçlarının ilgili literatürle birlikte değerlendirilmesi (literatüre duyarlılık), çalışmanın ilginç ve önemli olması.

Smith vd. (2009), Yin (1989) tarafından yapılan öneriye dayanarak, YFA çalışmalarında geçerliliğin bağımsız denetim (independent audit) ile sağlanabileceğini savunmuşlardır. Bağımsız denetim, bir araştırmanın ilk aşamasından araştırma raporunun yazılıp sunulduğu son aşamasına kadar kullanılan araştırma tasarımının tutarlı ve mantıklı bir şekilde uygulanıp uygulanmadığını kontrol etmeyi sağlayan bir geçerlilik stratejisidir (Smith vd., 2009). Bu bağlamda, YFA'yı doğasına uygun ve sistematik bir şekilde uygulayan bir araştırmanın geçerliliğinin yüksek olacağını söylemek uygun olacaktır. Bir YFA araştırmasının tüm basamaklarının (araştırma sorusunun geliştirilmesi, katılımcı grubunun belirlenmesi, veri oluşturma aşaması vb.) ve araştırmaya dair tüm dokümanların (saha notları, görüşmeler sırasında alınan ses kayıtları ve düşünümsel notlar, araştırmanın tasarı notları, araştırma raporu vb.) şeffaf bir şekilde kaydedilmesi bağımsız denetimin etkili bir şekilde gerçekleştirilmesini kolaylaştıracaktır.

\section{Metodoloji}

YFA ilgili literatür tarama sürecinde sistematik bir yaklaşım benimsenmiştir (örneğin, Rudolph, Murphy ve Zacher, 2020). Şekil 1'de YFA'ya yönelik gerçekleştirilmiş literatür tarama sürecini gösteren akış şeması yer almaktadır.

Web of Science (WoS) veri tabanı kullanılarak, 2021 yılı Mart ve Nisan aylarında YFA'yı araştırma tasarımı olarak kullanan makalelere ulaşılmaya çalışılmıştır. WoS veri tabanının seçilme sebebi yüksek etki değerine sahip ve kaliteli yayınların WoS kapsamında yer almasıdır. Sadece makale çalışmalarının 
örnekleme dahil edilme sebebi ise makale çalışmalarının hakem değerlendirmelerinden geçmiş olması ve geçerliliği sağlanmış, onaylanmış ve meşruiyeti olan bilgi birikimini daha iyi temsil etmesidir (Ramos-Rodríguez ve Ruíz-Navarro, 2004; Newman, Obschonka, Schwarz, Cohen ve Nielsen, 2019). Bu bağlamda, YFA ile ilgili çeşitli anahtar kelimeler (örneğin, "interpretative phenomenological analysis", "interpretative phenomenological approach", "interpretative phenomenological research") WoS kapsamındaki makalelerin başlıklarında, anahtar kelimelerinde ve özetlerinde taranmıştır. Ayrıca, literatür tarama sürecinde tespit edilen yüksek atıf almış makalelerin hem atıfları hem kaynakça listeleri YFA ile ilgili yapılmış çalışmaları tespit etmek açısından incelenmiştir. Fenomenoloji çalışmalarını yönetim alanında tanıtan çalışmaların kaynakça listesi de bu açıdan incelenmiştir.

Bu süreç sonunda toplamda 121 makaleye ulaşılmıştır. 121 makale içerisinde aynı makalenin bir veya birden fazla kopyası olan 65 makale (duplicate references) çalışmanın örnekleminden çıkartıldıktan sonra çalışma örnekleminde 56 makale kalmıştır. Bu makalelerin YFA'yı kullanıp kullanmadığının tespit edilmesi amacıyla başlık ve özet kısımları taranmıştır. Bu tarama sürecinde makalelerin başlığında veya özetinde fenomenoloji, yorumlayıcı fenomenoloji ve deneyim kavramlarından birisinin geçip geçmediğine dikkat edilmiştir. Bu kavramlardan herhangi birisine değinmeyen 2 makale veri kaynağından çıkarılmıştır. Böylece, veri kaynağında 54 makale kalmıştır.

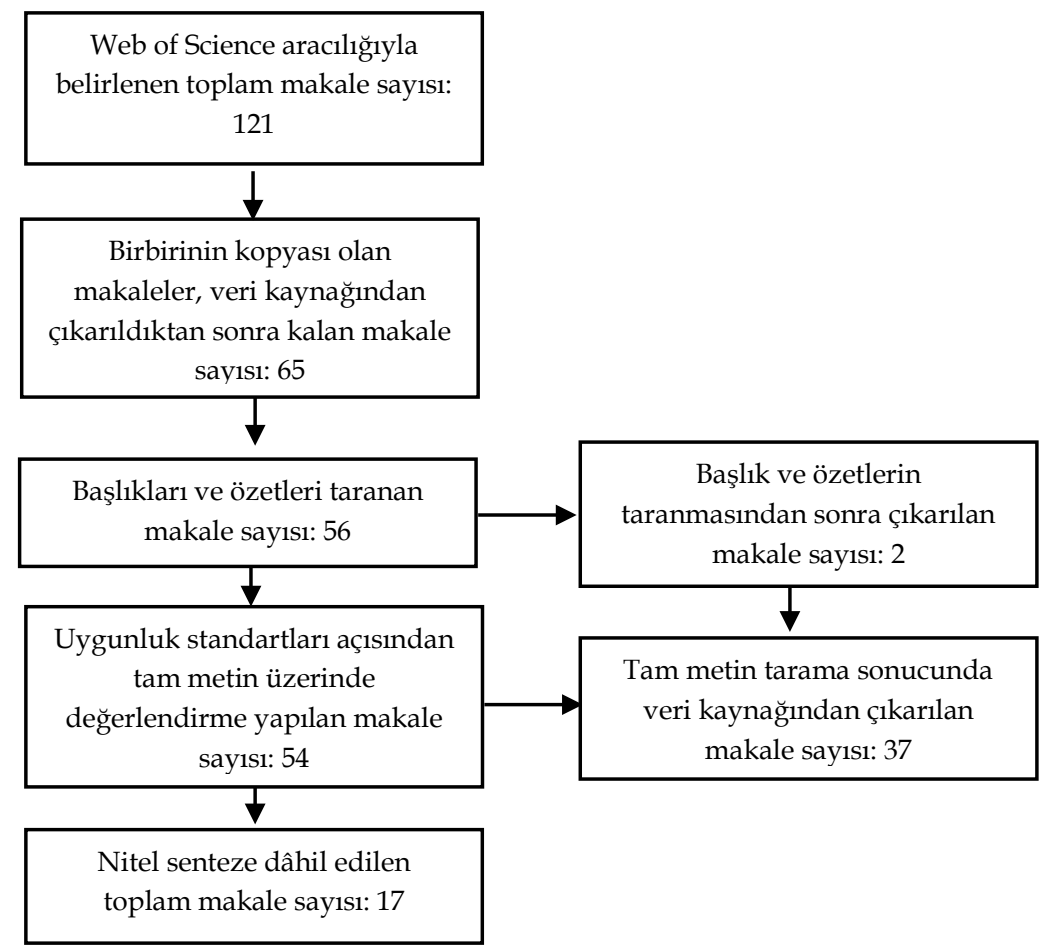

Şekil 1: Literatür Tarama Sürecinin Akış Şeması

Son aşamada, veri kaynağına dâhil etme kriterleri kapsamında 54 makalenin tam metninde derinlemesine tarama yapılmıştır. Çalışmanın amacı YFA'nın örgütsel bağlamda kullanım süreçlerini aydınlatmaktır. Bu anlamda, örneklemdeki çalışmaların YFA'yı araştırma tasarımında kullanması kriter olarak belirlenmiştir. Diğer bir deyişle, örneklemdeki çalışmaların temel aldığı yöntemin YFA olması gereklidir. Bu anlamda, YFA'yı örgütsel bağlamda tanıtan veya YFA ile ilgili kavramsal çalışma gerçekleştiren makaleler kapsam dışıdır. Dahası, YFA'yı sadece bir veri analiz aracı olarak kullanan, araştırma sorusu YFA'nın temel mantığı ile örtüşmeyen, katılımcıların deneyimlerini anlamlandırmayı merkeze almayan ve tümevarımsal süreçleri (inductive) benimsemeyen makaleler de kapsam dışı bırakılmıştır. Çünkü bu tarz çalışmaların bütüncül araştırma tasarımı, YFA'nın temel doğası ve özellikleriyle uyumlu değildir ya da bağdaşmamaktadır. Ayrıca, WoS kapsamındaki dergilerde sadece İngilizce dilinde yayınlanmış makaleler veri kaynağına dâhil edilmiştir. Makalelerin tam metninde bu uygunluk standartlarının karşılanmadığı 37 çalışma veri kaynağı dışında bırakılmıştır. Sonuç olarak, YFA'yı araştırma tasarımında kullanan 17 çalışma tespit edilmiştir. Böylece literatür tarama sürecinin gerçekleştirileceği örneklem süreci tamamlanmıştır.

YFA'yı araştırma tasarımında temel bir yöntem olarak kullanılan 17 çalışma aşağıdaki unsurlar açısından incelenmiştir: (1) amaç, (2) araştırma sorusu, (3) örneklem bilgisi, (4) sektör ve unvan bilgisi, (5) veri toplama yöntemi. 


\section{Bulgular}

Çalışmanın örnekleminde bulunan ve YFA'yı kullanan 17 çalışmanın tamamında örgütsel bağlamda deneyimlenen çeşitli fenomenlerin ele alındığı gözlemlenmiştir: annelik deneyimi (Millward, 2006), proje-temelli çalışmaya yönelik deneyimler (Rowlands ve Handy, 2012), bakıcı olma deneyimi (Tomkins ve Eatough, 2014), kimlik (Gill, 2015), cinsiyet pratikleri (de Miguel, Lizaso, Larranaga ve Arrospide, 2015), kariyer destek programlarının deneyimlenmesi (Snodgrass, Jenkins ve Tate, 2015), işyeri nezaketsizliği (Hodgins ve McNamara, 2017), örgütsel politikaların deneyimlenmesi (Landells ve Albrecht, 2017), korku (Gill ve Burrow, 2018), kariyer geçişi (Lane ve Lee, 2018), kutsal hallerin deneyimlenmesi (Jayawardena-Willis vd., 2019), güç (Berber ve Acar, 2020), çevrim içi uygulamaların kullanılmasına yönelik deneyimler (Hennekam, Macarthur, Bennett, Hope ve Goh, 2020), büyük veri ve iş analitiği deneyimi (Sengupta vd., 2020), girişimciliğe yönelik deneyimler (Williams vd., 2020), COVID-19 deneyimleri (Parlak vd., 2021) ve kültürlerarası uyum (Taylor, Everett ve Edgar, 2021). 17 çalışmanın araştırma sorularının odağında ise, deneyimler ve deneyimlere atfedilen bireysel anlamların keşfedilmesi temel motivasyon kaynă̆ı olarak yer aldığı görülmektedir.

YFA'yı kullanan araştırmaların katılımcı grubu bilgisiyle ilgili olarak; 9 çalışmada amaçlı örnekleme, 3 çalışmada amaçlı ve kartopu örnekleme, 1 çalışmada kolayda örnekleme, 1 çalışmada kolayda ve kartopu örnekleme ve 1 çalışmada kartopu ve kriter temelli örnekleme teknikleriyle katılımcı grubu belirleme süreçlerinin tasarlandığı gözlemlenmiştir.

Çalışmaların 2'sinde herhangi bir örnekleme tekniğinin belirtilmediği gözlemlenmiştir. Örgütsel bağlamdaki YFA araştırmalarının katılımcı profilinin cinsiyet dağılımları, araştırma sorusuna bağlı olarak yalnızca kadın, yalnızca erkek ya da hem kadın hem erkeklerden oluşmaktadır. Homojen katılımcı grubu benimseme konusunda, yalnızca 6 örgütsel YFA çalışmasında homojen katılımcı grubu vurgusu yapılırken, çalışmaların çoğunda katılımcı gruplarının homojen olup olmadığından bahsedilmemiştir.

Örgütsel YFA araştırmalarında hangi ülkelerden veri oluşturulduğuyla ilgili olarak, tek bir ülkede veri oluşturan çalışmalar bulunduğu gibi, birden fazla ülkede veri oluşturan çalışmaların da olduğu tespit edilmiştir. Tek bir ülkede veri oluşturan çalışmalardan 4'ü İngiltere'de, 2'si Yeni Zelanda'da, 1'i İspanya'da, 2'si Amerika'da, 1'i İrlanda'da, 1'i Avustralya'da, 1'i Sri Lanka'da, 1'i Hindistan'da ve 2'si Türkiye'de veri oluşturmuştur. 2 örgütsel YFA çalışmasının ise dünyanın çeşitli bölgelerinde bulunan birden fazla ülkeyi çalışmalarına dâhil ettikleri bulunmuştur. Bu 2 çalışmadan 1'inde özel olarak ülke isimleri belirtilmemekle birlikte, verilerin hangi kitalarda oluşturulduğu ifade edilmiştir.

Örgütsel alandaki YFA çalışmaları sektörel açıdan incelendiğinde, aynı sektörde faaliyet gösteren firmalarda çalışan kişilerin katılımcı grubu olarak belirlenmesi söz konusuyken, farklı sektörlerde yer alan firmalarda çalışan kişilerin de katılımcı grubu olarak belirlenmesi söz konusu olmuştur. Tek bir sektöre ulaşmayı hedefleyen örgütsel YFA çalışmaları; film yapımcılığı, taşımacılık, danışmanlık, eğitim, restoran, sağlık, müzik, bilgi teknolojileri gibi çeşitli sektörleri örnekleme almıştır. Birden fazla sektörü aynı çalışmada örneklem içerisine alan örgütsel YFA çalışmaları ise; kamu sektörü, özel sektör ve hizmet sektörü gibi sektörleri farklı kombinasyonlarla odağına almıştır. Bunun yanı sıra örgütsel YFA çalışmalarından bazıları, özel olarak bir sektörü örnekleme dâhil ettiğini belirtmemekle birlikte, hangi meslek gruplarının ya da unvana sahip kişilerin örnekleme aldığını belirtmiştir. Bu meslek gruplarından bazıları bakıcılık, öğretmenlik, avukatlık, yöneticilik, diş hekimliği, akademisyenlik, mühendislik vb. gibi çeşitli mesleklerdir. Örgütsel YFA çalışmalarının yalnızca bir tanesinde örnekleme hangi sektör ya da meslek grubunun dâhil edildiği belirtilmemiştir.

Bunlara ek olarak, örgütsel YFA çalışmalarının veri oluşturma yöntemleri ve bu çalışmalarda veri oluşturma aşamasının kaç kere gerçekleştiği tespit edilmeye çalışılmıştır. Bu bağlamda, 15 örgütsel YFA çalışmasında yalnızca yarı-yapılandırılmış görüşme yöntemi kullanılmıştır. Kalan 2 çalışmanın 1'inde yarı-yapılandırılmış görüşmelere ek olarak çeşitli yazılı dokümanlar da veri oluşturma aracı olarak kullanılmıştır. Diğer çalışmada ise görsel ve yaratıcı metotlar aracılığıyla yapılandırılmamış görüşmeler gerçekleştirilmiştir. Görüşmelerin kaç kez yapıldı̆̆ıyla ilgili olarak, çalışmaların 12'sinde katılımcılarla birer kez görüşme yapıldığı, kalan 5 çalışmada ise birden fazla görüşme yapıldığı tespit edilmiştir. Birden fazla görüşme yapılan çalışmaların bir tanesinde araştırma deseninin boylamsal olduğu belirtilmiştir.

Bunun yanı sıra, örneklemdeki YFA çalışmalarının hepsinin işletme ve iş/örgütsel psikoloji alanlarıyla ilgili dergilerde yayınlandığı tespit edilmiştir. Bu dergilerden bazıları Human Relations, Organization, The Career Development Quarterly, Journal of Occupational and Organizational Psychology, Journal of Organizational Change Management, International Journal of Cross Cultural Management ve Personnel Review gibi alanlarının en tanınmış dergileridir. 
Tablo 2: Örnek YFA Çalışmaları

\begin{tabular}{|c|c|c|c|c|c|c|}
\hline & Yazarlar & Amaç & Araştırma Sorusu & Katılımcı Grubu Bilgisi & Sektör ve Unvan & Veri Toplama Yöntemi \\
\hline 1 & $\begin{array}{l}\text { Millward (2006). } \\
\text { Journal of } \\
\text { Occupational and } \\
\text { Organizational } \\
\text { Psychology }\end{array}$ & $\begin{array}{l}\text { Kadın çalışanların gebelik süreci-gebelik } \\
\text { izni-işe geri dönme dönemlerindeki annelik } \\
\text { deneyimini nasıl anlamlandırdığına ilişkin } \\
\text { anlayış geliştirmek. }\end{array}$ & $\begin{array}{l}\text { Kadın çalışanlar örgütsel ortamda anneliğe } \\
\text { geçiş sürecini nasıl anlamlandırmaktadır? }\end{array}$ & $\begin{array}{l}\text { Amaçlı örnekleme. İngiltere. Gebelik } \\
\text { döneminde } 10 \text { kadın çalışan. Gebelik } \\
\text { sonrası dönemde işe yeniden başlayan } 8 \\
\text { çalışan. Homojen örnekleme } \\
\text { benimsenmiştir. }\end{array}$ & $\begin{array}{l}\text { Kamu (eğitim, sağlık, } \\
\text { Ar-ge) ve özel } \\
\text { (perakende, finans, } \\
\text { sigorta) sektör }\end{array}$ & $\begin{array}{l}\text { Yarı-yapilandırılmış } \\
\text { görüşme, } 2 \text { kez görüşme. }\end{array}$ \\
\hline 2 & \begin{tabular}{|l|} 
Rowlands ve \\
Handy (2012). \\
Human Relations
\end{tabular} & $\begin{array}{l}\text { Proje temelli yaratıcı işlerin çalışanlara } \\
\text { getirdiği içsel ödülleri ve dışsal kayıpları } \\
\text { derinlemesine anlamak. }\end{array}$ & $\begin{array}{l}\text { Serbest çalışan film yapımcılarının proje- } \\
\text { temelli çalışmaya yönelik sübjektif } \\
\text { deneyimleri nelerdir? }\end{array}$ & $\begin{array}{l}\text { Örneklem türü belirtilmemiş. Yeni Zelanda. } \\
11 \text { erkek ve } 10 \text { kadın katılımcı. Homojen } \\
\text { örneklemeden bahsedilmemiş. }\end{array}$ & Film yapımcıllğı sektörü & $\begin{array}{l}\text { Yarı-yapılandırılmış } \\
\text { görüşme, } 1 \text { kez görüşme. }\end{array}$ \\
\hline 3 & \begin{tabular}{|l} 
Tomkins ve \\
Eatough (2014). \\
Organization
\end{tabular} & $\begin{array}{l}\text { Bakıcı olarak çalışmanın kişisel, deneyimsel } \\
\text { ve var oluşsal anlamlarını keşfetmek. }\end{array}$ & $\begin{array}{l}\text { Bakıcı olarak çalışmak nasıl bir } \\
\text { deneyimdir? }\end{array}$ & $\begin{array}{l}\text { Amaçlı örnekleme. İngiltere. } 8 \text { kadın. } \\
\text { Homojen örnekleme benimsenmiştir. }\end{array}$ & $\begin{array}{l}\text { Kamu sektöründe yer } \\
\text { alan destek grupları } \\
\text { içerisinde bulunan } \\
\text { bakıcılar }\end{array}$ & $\begin{array}{l}\text { Yarı-yapılandırılmıss } \\
\text { görüşme, } 1 \text { kez görüşme. }\end{array}$ \\
\hline 4 & $\begin{array}{l}\text { Gill (2015). } \\
\text { Organization. }\end{array}$ & $\begin{array}{l}\text { Örgütsel bağlamda kimlik düzenlemesi ve } \\
\text { inşasının çalışanlar için anlamını ve } \\
\text { psikolojik etkilerini anlamlandırmak. }\end{array}$ & $\begin{array}{l}\text { Yöneticilerin danışmanları "danışman" } \\
\text { kimliklerini nasıl anlamlandırırlar? } \\
\text { Yöneticilerin danışmanları için kimlik } \\
\text { inşasının psikolojik etkileri nelerdir? }\end{array}$ & $\begin{array}{l}\text { Amaçlı örnekleme. İngiltere. } 8 \text { erkek } \\
\text { katılımc1. Homojen örneklemeden } \\
\text { bahsedilmemiş. }\end{array}$ & Danışmanlık sektörü & \begin{tabular}{|l} 
Yarı-yapılandırılmış \\
görüşme, 1 kez görüşme.
\end{tabular} \\
\hline 5 & \begin{tabular}{|l|} 
Gill ve Burrow \\
(2018). Organization \\
Studies
\end{tabular} & $\begin{array}{l}\text { 1.Kurumsal bağlamda korkunun } \\
\text { fonksiyonu ve anlamını anlamlandırmak } 2 \text {. } \\
\text { Kurumların devamlılığı üzerinde } \\
\text { duyguların oynadığı rolü anlamak }\end{array}$ & $\begin{array}{l}\text { Çalışanların korkuya ilişkin deneyimleri } \\
\text { kurumsal süreçleri nasıl etkiler? }\end{array}$ & $\begin{array}{l}\text { Amaçlı örnekleme. Amerika, Avustralya, } \\
\text { Belçika, Kanada, Danimarka, Fransa, Çin, } \\
\text { Singapur, İspanya, İtalya ve İngiltere. } 7 \\
\text { kadın ve } 23 \text { erkek katıllmcı. Homojen } \\
\text { örneklemeden bahsedilmemiş. }\end{array}$ & Restoran. & \begin{tabular}{|l|} 
Çeşitli yazılı dokümanlar, \\
yarı-yapılandırılmış \\
görüşme, 1 kez görüşme.
\end{tabular} \\
\hline 6 & $\begin{array}{l}\text { Berber ve Acar } \\
\text { (2020). Human } \\
\text { Relations }\end{array}$ & $\begin{array}{l}\text { İşyerinde gücün nasıl inşa edildiğini, } \\
\text { çalışanlar için ne anlama geldiğini ve gücü } \\
\text { şekillendiren niyet ve stratejileri anlamak. }\end{array}$ & $\begin{array}{l}\text { Çalışanlar için "güç" ne anlama } \\
\text { gelmektedir? }\end{array}$ & $\begin{array}{l}\text { Amaçlı örnekleme. Türkiye. } 11 \text { erkek } \\
\text { katılımc1. Homojen örnekleme } \\
\text { benimsenmiştir. }\end{array}$ & $\begin{array}{l}\text { Üretim ve servis } \\
\text { sektörleri }\end{array}$ & $\begin{array}{l}\text { Yarı-yapılandırılmış } \\
\text { görüşme, } 1 \text { kez görüşme. }\end{array}$ \\
\hline
\end{tabular}


Tablo 2'de örneklemde bulunan bazı YFA çalışmaları örnek olarak gösterilmiştir. Bu çalışmanın araştırma bulgularıyla ilgili olarak, amaç cümlesi kapsamında YFA araştırmalarının hangi fenomene odaklandığı aydınlatılmaya çalışılmıştır. Araştırma sorusuyla ilgili kısımda, belli bir deneyimin ve deneyime yönelik katılımcıların anlam verme sürecinin temel alınıp alınmadığına dikkat edilmiştir

Katılımcı grubu bilgisi maddesinde, hangi örnekleme türünün benimsendiği, hangi ülkede veri oluşturulduğu, katılımcıların cinsiyetlerine göre sayısı ve homojen örnekleme sürecine değinilip değinilmediği aydınlatılmaya çalışılmıştır. Sektör ve unvan başlığında ise katılımcıların hangi sektörlerden seçildiği ve unvanlarının neler olduğu açılanmaya çalışılmıştır. Veri oluşturma yönteminde ise, verilerin hangi yöntemle oluşturulduğu ve eğer görüşme yapıldıysa katılımcılarla kaç kere görüşüldüŭgünün dokümantasyonu amaçlanmıştır. Ayrıca, çalışmaların yazar ve dergi bilgileri verilmiştir.

\section{Tartışma}

Bu çalışma kapsamında, örgütsel alan yazınında YFA'yı bir araştırma deseni olarak kullanan ampirik çalışmalar amaç, araştırma sorusu, örneklem, sektör ile unvan bilgisi ve veri yöntemi açısından analiz edilmiştir. Çalışma, YFA'yı kullanan örgütsel araştırmaları inceleyen ilk sistematik inceleme olma özelliği taşımaktadır. Özellikle, bu çalışmada YFA'nın doğası ve temel özellikleri tanıtılmış ve örneklemdeki makaleler bu çerçevede değerlendirilmiştir.

Bu çalışmada gelecek makalelere YFA'yı sadece bir nitel analiz yöntemi olarak değil, nitel araştırma deseni olarak kullanmaları yönünde bir vurgu yapılmaktadır. Diğer bir deyişle, araştırma probleminin belirlenmesinden araştırma sonuçlarının yorumlanması aşamasına kadar, YFA'nın doğasına sadık kalınması yüksek kaliteli ve geçerli YFA çalışmalarının ortaya çıkmasındaki en önemli adımdır. Bu açıdan, çalışma örneklemine dâhil edilen araştırmalar, yöntemsel olarak YFA'nın doğasına uygun bir şekilde yapıldığı ve WoS'ta taranan yüksek etki değerine sahip yayınlar olduğu için yüksek kaliteli YFA çalışmaları olarak değerlendirilebilir. Dolayısıyla, bu çalışma, gelecekte yapılacak yüksek kaliteli YFA çalışmalarına ışık tutan bir kılavuz görevi üstlenerek örgütsel alan yazınına metodolojik açıdan katkı sağlamayı amaçlamıştır.

Bu çerçevede, YFA'da araştırma sorusunun deneyimsel olması ve fenomenin tümevarımsal bir şekilde incelenmesi önemsenmektedir (Smith, 2019). Diğer bir deyişle, yüksek kaliteli YFA çalışmalarının ortaya çıkması için, araştırmanın temel odağının bir deneyimin "anlamı" üzerine olması ve deneyimlerin önceden belirlenmiş neden-sonuç ilişkileri çerçevesinde incelenmemesi önerilir (Smith, 2004). Bu bağlamda, örneklemde bulunan ve çeşitli fenomenleri konu edinen çalışmalarda örgütsel bağlamda yaşanan deneyimlerin çalışanlar için "ne anlama" geldiğinin derinlemesine araştırıldığı tespit edilmiştir. Smith (2019) tarafından yapılan çalışmada anlam tipolojilerinden üçüncü düzeyin ("Bunun anlamı nedir?" sorusuna odaklanmaktadır) YFA'nın deneyimsel doğasına uygun olduğu belirtilmiştir. Örneklemde bulunan çalışmalardan bazıları araştırma sorularında ilgili deneyimin "anlamının" araştırılacağını açık bir şekilde ifade etmese de bu çalışmaların amaç cümlelerinden katılımcıların "sübjektif" deneyimlerinin araştırıldığı anlaşılmaktadır. Bu sebeple, örneklemde bulunan çalışmaların araştırma soruları, Smith vd.'nin (2019) tipolojisine uygun olarak, deneyimsel analiz düzeyini yansıtmaktadır. Gelecek çalışmaların araştırma sorularında deneyimin anlamının odak noktası olması, araştırma sorusunun anlaşılabilirliğine katkı sağlayabilir.

Katılımcı grubu bilgisi açısından, çalışmaların çoğu YFA'ya uygun olarak amaçlı örnekleme ya da amaçlı örnekleme kategorisinde olan örneklem yöntemleriyle (örneğin, kartopu örnekleme) katılımcılara ulaşmıştır. Ancak bazı çalışmalar hangi örnekleme yöntemini kullandığını belirtmemiştir. Dolayısıyla bu çalışmalarda örnekleme yönteminin YFA'ya uygun olmadığı tartışma konusudur. Bir YFA çalışmasında katılımcı grubunun amaçlı örnekleme yoluyla oluşturulduğunun belirtilmesi, katılımcıların ilgili deneyim hakkında zengin ve detaylı paylaşımlarda bulunacak kişilerden seçildiği bilgisini işaret etmesi açısından önem taşımaktadır (Smith vd., 2009). Gelecek çalışmalar, araştırmanın YFA araştırma desenine uygun bir şekilde yapıldığını bildirmek için örnekleme yöntemi bilgisini açık bir şekilde paylaşmalıdırlar.

Bunun yanı sıra, katılımcı grubunun homojen bir şekilde oluşturulması YFA'nın en temel özelliklerinden birisi olmasına rağmen, örneklemdeki araştırmaların az bir kısmı (6 makale) homojen örneklemeyi benimsediğini ifade etmiştir. Bu yüzden okuyucular, YFA çalışmalarında katılımcıların araştırılan deneyime yönelik ortak bir bakış açısına sahip olup olmadı̆̆ı konusunda bir yorum yapamayabilir. Bu problem, çalışmaların sonucunda, katılımcı grubu içindeki benzerlik ve farklılıkların etkili ve zengin bir şekilde ortaya çıkarılıp çıkarılmadığı hakkında bir soru işareti oluşmasına sebep olmaktadır. Ayrıca önceki çalışmaların tekrarını yapacak gelecek YFA çalışmalarına yol göstermesi açısından, katılımcı grubunda homojenliği sağlayan değerlendirme ve seçme ölçütlerinin paylaşılması 
önem arz etmektedir. Bu sebeple, gelecek YFA çalışmalarının hem homojen örneklemenin benimsendiğinden hem de katılımcı grubunun hangi ölçütlere göre homojenleştirildiğinden bahsetmeleri çalışmanın etkililiğine ve aktarılabilirliğine katkı sağlayabilir.

Ülke açısından örgütsel YFA çalışmaların çoğunun İngiltere'de yapıldığ tespit edilmiştir. Böyle bir sonucun ortaya çıkmasında, YFA'nın İngiltere'de gelişen bir yöntem olması ve yaygın bir şekilde kullanılıyor olması etkili bir rol oynamış olabilir (Smith, 2011). Ayrıca Türkiye bağlamında yalnızca iki çalışmanın yapılması, Türkçe örgütsel alan yazınında YFA'nın bir araştırma deseni olarak yeterince tanınmadığı ve kullanılmadığı şeklinde yorumlanabilir. Özellikle pozitivist anlayışın etkisiyle anket ve istatistiksel verilere dayalı nicel araştırma yöntemlerinin hâkim olduğu yönetim ve organizasyon alan yazınında (Berber, 2017) ve bu egemen araştırma yöntemi yöneliminin oldukça kabul gördüğü Türkiye bağlamında nitel bir yöntem olan YFA'nın tanıtılması ilgili literatürlere yeni bakış açıları kazandırarak önemli bir katkıda bulunacaktır.

Nitel araştırmalarda, araştırmacının öznelliğinin bulguların tarafsız ve nesnel bir şekilde elde edilmesine engel olduğuna yönelik eleştiriler, veri oluşturma ve analiz etmenin zaman alıcı bulunması ve çaba gerektirmesi (Tracy, 2020) ve geçerlilik-güvenirlilik sorunlarının çözümü üzerine bir fikir birliğine varılamaması (Merriam ve Tisdell, 2016) gibi sebepler yönetim ve organizasyon araştırmalarında nitel araştırma yöntemlerinin daha az tercih edilmesine neden olan potansiyel faktörler olarak gösterilebilir. Ancak Türkiye'de düzenlenen Ulusal Yönetim ve Organizasyon Kongresi'nde özellikle son yıllarda örgütsel davranış alanında sunulan bildirilerde nitel araştırma yöntemlerinin daha sık kullanıldı ̆̆ı görülmektedir (Kızıldağ ve Özkara, 2016). Bu nedenle, nitel bir yöntem olan YFA yaklaşımının Türkiye bağlamında benimsenmeye ve gelişmeye açık önemli bir potansiyel taşıdığı düşünülmektedir. Özellikle Smith (2011) İngilizce konuşulmayan ülkelerde YFA çalışmalarının yapılması yönünde bir araştırma çağrısında bulunmuştur. Araştırmacıların fenomen odaklı çalışmalarında YFA yöntemini kullanmaları, Türkiye bağlamında örgütsel ortamda yaşanan deneyimlerin ve bu deneyimlere yüklenen anlamların zengin bir şekilde anlaşılmasına katkı sağlayacaktır. Bunun yanı sıra, YFA'da deneyimler ortaya çıktıları bağlamla birlikte anlamlandırılmaya çalışılır (Smith vd., 2009). Bu yüzden, Türkiye'de çalışanların yaşadıkları deneyimleri bu bağlama özgü özelliklerle ilişkilendirerek anlamak, çalışma hayatındaki problemlerin çözümlerine pratik açıdan katkı sağlayacaktır. Ayrıca, sektör bilgisi açısından, örneklemde bulunan YFA çalışmaları hizmet, sağlık, eğitim, kamu, üretim ve bilgi teknolojileri gibi çeşitli sektörlere odaklanmışlardır. Bu bağlamda, gelecek çalışmalar herhangi bir kısıtlama olmaksızın çeşitli sektörlerde yaşanan canlı ve önemli deneyimleri inceleyen çalışmalar yapabilirler.

Öte yandan, yarı-yapılandırılmış görüşmeler, bireysel deneyimlerin ve anlamlandırmaların zengin bir şekilde açığa çıkarıldığı ve bu yüzden de YFA çalışmalarında en yaygın şekilde kullanılan veri oluşturma yöntemidir (Smith vd., 2009). YFA'nın temel özellikleriyle örtüşen şekilde, örneklemdeki YFA çalışmalarında veri oluşturma yöntemi olarak yarı-yapılandırılmış görüşmeler tercih edilmiştir. Çalışmaların çoğunda birer kez yarı yapılandırılmış görüşmeler yapılmış olup, bazılarında ise katılımcılarla birden fazla görüşmeler yapılmıştır. Katılımcılar bazen tek bir görüşmede yeterli ve zengin paylaşımlarda bulunmayabilirler. Böyle bir durum, katılımcının deneyiminin derin bir şekilde anlaşılmasını kısıtlayacağı için, katılımcıyla birden fazla görüşme yapılmasında fayda olabilir. Bununla birlikte, farklı zaman noktalarında birden fazla görüşmelerin yapılması deneyimlerin süreç içinde geçirdiği değişimleri ve anlamların farklılaşıp farklılaşmadı̆̆ını anlamak açısından önem arz etmektedir. Özellikle zamansal boyutu olan fenomenleri incelemeyi amaçlayan araştırmalar boylamsal araştırma tasarımı ile YFA'yı entegre ederek kullanabilirler (McCoy, 2017). Böyle bir araştırma yönelimi deneyimlerin bağlam ve zamanla ilişkili olarak zengin bir şekilde anlaşılmasına da olanak sağlayacaktır.

Bunun yanı sıra, bazı çalışmalar yarı-yapılandırılmış görüşmelere ek olarak yazılı dokümanlar, görsel ve yaratıcı metotları (oyuncak lego gibi) veri toplama aracı olarak kullanmışlardır. Görsel araştırma yöntemleri, örgütsel çalışmalarda bazı hassas konuların ya da karmaşık deneyimlerin sözel olarak ifade edilmesini kolaylaştırdığı gibi deneyimlerin zaman, mekân ya da bireylerarası yönlerinin imgeler ve metaforlar aracılığıyla ulaşılmasına da olanak sağlamaktadır (Boden, Larkin ve Iyer, 2019). Bu bağlamda, gelecek YFA çalışmalarında, katılımcılarının paylaşımlarının zenginleştirilmesi amacıyla ilginç ve yaratıcı yöntemleri (çizim, boyama, rol yapma (role-playing) görüşmelere ek veri toplama aracı olarak kullanılabilir.

Ayrıca gelecek YFA araştırmalarının yüksek kaliteli olması ve geçerliliğin sağlanması için Smith vd. (2009) tarafından sunulan kriterlerin dikkate alınması ve ilgili stratejilerin benimsenmesi önerilmektedir. Ancak YFA'da kalite ve geçerlilik konuları ele alınırken, güvenirlilik sorunsalının yeterince irdelenmediği tespit edilmiştir. Bu doğrultuda, gelecek çalışmalarda YFA'da geçerlilik ve 
güvenirlilik konularının kapsayıcı bir şekilde ele alınması YFA araştırmalarının daha kaliteli ve özenli bir şekilde yapılmasına yardımcı olacaktır.

\section{Hakem Değerlendirmesi / Peer-review:}

Dış bağımsız

Externally peer-reviewed

\section{Çıkar Çatışması / Conflict of interests:}

Yazar(lar) çıkar çatışması bildirmemiştir.

The author(s) has (have) no conflict of interest to declare.

\section{Finansal Destek / Grant Support:}

Yazar(lar) bu çalışma için finansal destek almadığını beyan etmiştir.

The author(s) declared that this study has received no financial support.

\section{Yazar Katkıları / Author Contributions:}

Fikir/Kavram/Tasarım - Idea/Concept/ Design: H.K., Z.A., S.Ş.F., Veri Toplama ve/veya İşleme - Data Collection and/or Processing: H.K., Z.A., S.Ş.F., Analiz ve/veya Yorum - Analysis and/or Interpretation: H.K., Z.A., S.Ş.F., Kaynak Taraması - Literature Review: H.K., Z.A., S.Ş.F., Makalenin Yazımı - Writing the Article: H.K., Z.A., S.Ş.F., Eleştirel İnceleme - Critical Review: H.K., Z.A., S.Ş.F., Onay - Approval: H.K., Z.A., S.Ş.F.

\section{Kaynakça / References}

Ahn, J., Dik, B.J. ve Hornback, R. (2017). The experience of career change driven by a sense of calling: An Interpretative Phenomenological Analysis approach. Journal of Vocational Behavior, 102, 48-62.

Berber, A. (2017). Yönetimde kavramsal çerçeve belirleme ve nitel araştırma yöntemleri. İstanbul Üniversitesi İşletme Fakültesi Dergisi, 46(Özel say1), 71-73.

*Berber, A. ve Acar, A. G. (2020). Power crafting at work: A phenomenological study on individual differences. Human Relations. https://doi.org/10.1177/0018726720942828

Boden, Z., Larkin, M. ve Iyer, M. (2019). Picturing ourselves in the world: Drawings, interpretative phenomenological analysis and the relational mapping interview. Qualitative Research in Psychology, 16(2), 218-236.

*De Miguel, M. S., Lizaso, I., Larranaga, M. ve Arrospide, J. J. (2015). Women bus drivers and organizational change. Journal of Organizational Change Management, 28(1), 117133. https:// doi.org/10.1108/JOCM-07-2013-0120

Dias, A. R. ve Teixeira, A. A. (2017). The anatomy of business failure: A qualitative account of its implications for future business success. European Journal of Management, 26, 2-20.

Gill, M. J. (2014). The possibilities of phenomenology for organizational research. Organizational Research Methods, 17(2), 118-137.

${ }^{*}$ Gill, M. J. (2015). Elite identity and status anxiety: An interpretative phenomenological analysis of management consultants. Organization, 22(3), 306-325.

*Gill, M. J. ve Burrow, R. (2018). The function of fear in institutional maintenance: Feeling frightened as an essential ingredient in haute cuisine. Organization Studies, 39(4), 445-465.

*Hennekam, S., Macarthur, S., Bennett, D., Hope, C. ve Goh, T. (2020). Women composers' use of online communities of practice to build and support their careers. Personnel Review, 49(1), 215-230. 
*Hodgins, M. ve McNamara, P. (2017). Bullying and incivility in higher education workplaces: Micropolitics and the abuse of power. Qualitative Research in Organizations and Management: An International Journal, 12, 190-206.

*Jayawardena-Willis, T. S., Pio, E. ve McGhee, P. (2019). The divine states (brahmaviharas) in managerial ethical decision-making in organisations in Sri Lanka: An interpretative phenomenological analysis. Journal of Business Ethics, 1-21.

Kızıldağ, D. ve Özkara, B. (2016). Türkiye'de örgütsel davranış araştırmalarındaki yönelimler: Ulusal Yönetim ve Organizasyon Kongresi Örneği*. Yönetim Bilimleri Dergisi, 14(28), 611-631.

*Landells, E. M. ve Albrecht, S. L. (2017). The positives and negatives of organizational politics: A qualitative study. Journal of Business and Psychology, 32(1), 4158. https://doi.org/10.1007/s10869-015-9434-5

*Lane, A. ve Lee, D.L. (2018). Career transitions of highly skilled immigrants: Two case studies. The Career Development Quarterly, 66, 315-328.

Larkin, M., Eatough, V. ve Osborn, M. (2011). Interpretative phenomenological analysis and embodied, active, situated cognition. Theory \& Psychology, 21(3), 318-337.

Larkin, M., Shaw, R. ve Flowers, P. (2019). Multiperspectival designs and processes in interpretative phenomenological analysis research. Qualitative Research in Psychology, 16(2), 182-198.

Mathieu, J. E. (2016). The problem with [in] management theory. Journal of Organizational Behavior, 37(8), 1132-1141.

McCoy, L. K. (2017). Longitudinal qualitative research and interpretative phenomenological analysis: philosophical connections and practical considerations. Qualitative Research in Psychology, 14(4), $442-458$

Merriam, S. B. ve Tisdell, E. J. (2016). Qualitative research: A guide to design and implementation (4. ed.). San Francisco, CA: Jossey-Bass.

*Millward, L. J. (2006). The transition to motherhood in an organizational context: An interpretative phenomenological analysis. Journal of Occupational and Organizational Psychology, 79(3), 315-333.

Newman, A., Obschonka, M., Schwarz, S., Cohen, M. ve Nielsen, I. (2019). Entrepreneurial self-efficacy: A systematic review of the literature on its theoretical foundations, measurement, antecedents, and outcomes, and an agenda for future research. Journal of Vocational Behavior, 110, 403-419.

*Parlak, S., Celebi Cakiroglu, O. ve Oksuz Gul, F. (2021). Gender roles during COVID-19 pandemic: The experiences of Turkish female academics. Gender, Work \& Organization. https://doi.org/10.1111/gwao.12655

Ployhart, R. E. ve Bartunek, J. M. (2019). Editors' comments: There is nothing so theoretical as good practice-A call for phenomenal theory. Academy of Management Review, 44(3), 493-497.

Ramos-Rodríguez, A.-R. ve Ruíz-Navarro, J. (2004). Changes in the intellectual structure of strategic management research: a bibliometric study of the Strategic Management Journal, 1980-2000. Strategic Management Journal, 25, 981-1004.

*Rowlands, L. ve Handy, J. (2012). An addictive environment: New Zealand film production workers' subjective experiences of project-based labour. Human Relations, 65(5), 657-680.

Rudolph, C. W., Murphy, L. D. ve Zacher, H. (2020). A systematic review and critique of research on "healthy leadership". The Leadership Quarterly, 31(1), 101335.

*Sengupta, A., Mittal, S. ve Sanchita, K. (2020). How do mid-level managers experience data science disruptions? An in-depth inquiry through interpretative phenomenological analysis (IPA). Management Decision. https://doi.org/10.1108/MD-01-2020-0099

Schwarz, G. ve Stensaker, I. (2014). Time to take off the theoretical straightjacket and (re-)introduce phenomenon-driven research. The Journal of Applied Behavioral Science, 50(4), 478-501.

Schwarz, G. M. ve Stensaker, I. G. (2016). Showcasing phenomenon-driven research on organizational change. Journal of Change Management, 16(4), 245-264.

Smith, J. A. (2004). Reflecting on the development of interpretative phenomenological analysis and its contribution to qualitative research in psychology. Qualitative Research in Psychology, 1(1), 39-54. 
Smith, J. A. (2011). Evaluating the contribution of interpretative phenomenological analysis. Health Psychology Review, 5(1), 9-27.

Smith, J. A. (2019). Participants and researchers searching for meaning: Conceptual developments for interpretative phenomenological analysis. Qualitative Research in Psychology, 16(2), 166-181.

Smith, J. A., Flowers, P. ve Larkin, M. (2009). Interpretative phenomenological analysis: Theory, method, and research. Thousand Oaks, CA: Sage.

Smith, J. A. ve Osborn, M. (2015). Interpretative phenomenological analysis. J. A. Smith (Yay. haz.). Qualitative psychology: A practical guide to research methods (ss. 25-53). London: Sage.

*Snodgrass, J. L., Jenkins, B. B. ve Tate, K. F. (2017). More than a job club, sister: Career intervention for women following incarceration. The Career Development Quarterly, 65, 29-43.

*Taylor, Y., Everett, A. M. ve Edgar, F. (2021). Perception of cross-cultural adjustment by immigrant professionals from three ethnic groups in one host context. International Journal of Cross Cultural Management.

*Tomkins, L. ve Eatough, V. (2014). Stop 'helping' me! Identity, recognition and agency in the nexus of work and care. Organization, 21(1), 3-21.

Tracy, S. J. (2020). Qualitative research methods: Collecting evidence, crafting analysis, communicating impact (2. Ed.). Hoboken, NJ: John Wiley \& Sons.

Trede, F. ve Higgs, J. (2009). Framing research questions and writing philosophically: The role of framing research questions. In Writing Qualitative Research on Practice (2 ed., ss. 13-26). Sense Publishers.

Van de Ven, A. H. (2016). Happy birthday, AMD! Academy of Management Discoveries, 2(3), 1-3.

${ }^{*}$ Williams, H. C., Pritchard, K., Miller, M. C. ve Reed, C. (2020). Climbing to freedom on an impossible staircase: Exploring the emancipatory potential of becoming an entrepreneuremployer. International Small Business Journal. https://doi.org/10.1177/0266242620967613

Yardley, L. (2000). Dilemmas in qualitative health research. Psychology \& Health, 15, 215-228.

Yin, R. (1989). Case Study Research: Design \& Methods (2. ed). Beverly Hills: Sage.

Yıldız (*) işareti, bu çalışma kapsamında incelenmek üzere örnekleme dâhil edilen makaleleri göstermektedir. 